
английского языка: этимологический анализ

\author{
Белгородский государственный национальный \\ исследовательский университет, \\ ул. Победы, 85, г. Белгород, 308013, Россия \\ E-mail: master.gothic@yandex.ru \\ ORCID: 0000-0001-8233-3826
}

Статья поступила 7 марта 2020 г.; принята 3 июня 2020 г.; опубликована 30 июня 2020 г.

Аннотация. В статье проводится анализ происхождения английских слов, которые были заимствованы из арабского языка. В качестве материальной базы и опорной точки данного исследования послужило художественное произведение «Тысяча и одна ночь». Выбор именно этого сборника рассказов обоснован тем, что являясь, по мнению многих исследователей, продуктом фольклора, именно эта книга вобрала в себя множество аспектов, которые являются в значительной степени отражением арабского мировосприятия и менталитета. Поэтому некоторые из арабизмов в английском языке интересно было изучить именно в таком контексте. Для визуальной простоты восприятия к каждому слову прилагается схематическая “история” его проникновения в английский язык.

Актуальность данного исследования обусловлена малой степенью изученности арабских заимствований в контексте литературных произведений. На основе данного факта, возникает проблема отсутствия исчерпывающих работ, анализирующих степень использования слов арабского происхождения в англоязычной литературе.

Для формирования базы анализа была сделана случайная выборка пятнадцати наиболее распространенных и используемых в наши дни слов, имеющих арабские корни. Основные используемые методы: сравнение, абстрагирование, анализ и синтез, описательный метод.

На основе проведенного анализа было выявлено, что большая часть арабизмов пришли в английский не напрямую, а через другие европейские языки, в большей степени через французский. На основе этого можно сделать вывод о том, что французский язык имел существенную роль в формировании английской лексики, и в частности основным «транслятором» арабизмов.

Ключевые слова: арабизм; языковые заимствования; Тысяча и одна ночь; языкпосредник; английский язык; этимологический анализ; арабский фольклор.

Информация для цитирования: Еремин А.С. Арабские заимствования в лексико-семантической системе английского языка: этимологический анализ // Научный результат. Вопросы теоретической и прикладной лингвистики. 2020. T.6,N2. C. 14-25. DOI: 10.18413/2313-8912-2020-6-2-0-2 


\title{
Alexander S. Eremin $\quad$ Arabic Borrowings in the Lexical-Semantic System of the English Language: Etymological Analysis
}

\author{
Belgorod State National Research University \\ 85 Pobedy St., Belgorod, 308013, Russian Federation \\ E-mail: master.gothic@yandex.ru \\ ORCID: 0000-0001-8233-3826
}

$\underline{\text { Received } 7 \text { March 2020; accepted } 3 \text { June 2020; published } 30 \text { June } 2020}$

\begin{abstract}
The analysis of the origin of English words that were borrowed from the Arabic is given in the article. The base and reference point of this study is the work of art "One Thousand and One Nights" in its modern translation by Penguin Classics. The choice of this particular collection of stories is justified by the fact that, in opinion of many researchers, as a product of folklore, this book incorporated many aspects that are largely a reflection of the Arab worldview and mentality. Therefore, it was interesting to study some of the Arabisms in English in that context. For visual simplicity of perception, a schematic "history" of its penetration into English is attached to each described word.

The relevance of this study is due to the low degree of knowledge of Arabic borrowings in the context of literary works. Based on this fact, the problem arises of the lack of comprehensive works analyzing the degree of use of words of Arabic origin in English literature.

To create the analysis base, fifteen most common and used words with Arabic roots were chosen. The main methods used: comparison, abstraction, analysis and synthesis, descriptive method.

Based on the analysis, it was revealed that most of the Arabisms came to English not directly, but through other European languages, to a greater extent through French. Based on this, we can conclude that the French language had a significant role in the formation of English vocabulary, and in particular the main "transmitter" of Arabisms.

Key words: Arabism; loanwords; The Thousand and One Nights; Intermediary language; English; etymological analysis; Arabic folklore

How to cite: Eremin A.S. (2020). Arabic Borrowings in the Lexical-Semantic System of the English Language: Etymological Analysis. Research Result. Theoretical and Applied Linguistics, V.6 (2), 14-25, DOI: 10.18413/2313-8912-2020-6-2-0-2
\end{abstract}

\section{Introduction}

Fiction is one of the most ancient and effective non-verbal methods representing the national flavor of a particular culture. Even if we take into account that any work of fiction is translated so that it could be perceived by a bearer of another culture (language), and some of the unique lexical features may be lost or unreliable, cultural realities, despite this, are still reflected in the text (Hock, 1996). This is due primarily to the fact that any national culture is based on its own unique picture of the world, which in turn is inextricably linked with the history of the people. Despite the fact that most of the lexical units from the Arabic language penetrated into English naturally - through cultural contacts and assimilation of Arabic 
and European speakers, literature also contributed to this process.

This article is based on the context analysis of words of Arab origin from the famous work of "One Thousand and One Nights." This work was chosen as an object of research, because it is the result of not only one author-representative of the Arab culture, but in fact, it is folk art. Various researchers put forward different theories about the origin of this storybook, but they failed to come to agreement or identify a specific author (Adzieva, 2014: 17). "One Thousand and One Nights" is a collection of ancient eastern folk tales, compiled around the time of the Golden Age of Islam (8-14th c.). This collection is also known as "Arabian Nights" according the very first translation into English. The history of the "Arabian nights" is complex and confusing. Many scientists have tried to trace the path that this book has gone since its origin until nowadays [Fassler, 8].

The very first European version was the translation into French (1704-1717) by Anthony Galland (Anchi, 2017). These translations were based on the Syriac version of the Arabic text. A curious moment was that Galland also included in his collection such tales as "The Lamp of Aladdin" and "Alibaba and the Forty Thieves", which first appeared in his translation, but were not in the original version of the manuscript. Later, another translation by Edward Lane $(1840,1859)$ appeared. This version of the translation is still considered one of the classic translations of the "Arabian Nights," since it was as close as possible to the original, in contrast to the translations of Galland (Salye, 2009).

In 2008, Penguin Classics released a new version of the three-volume story collection. In addition to the original text of the book "One Thousand and One Nights", this edition contains the stories of Aladdin, Ali Baba, as well as an alternative ending to "Seven Adventures of Sinbad" from a translation by Anthony Galland.

This version of translation was taken as the basis of the analysis of Arabisms in the text, since it is more consistent with modern lexical norms.

\section{Main part}

The main purpose of this study is an attempt to trace and conduct an etymological analysis of words of Arabic origin in English in the context of fiction. In this regard, we selected 15 lexical units of Arabic origin representing various semantic fields.

\section{1) Giraffe}

"The Muslims pursued them with their Indian swords and only a few of the elephants and giraffes escaped." (Lyons, 2008: night 664)

This designation of the animal comes from the Arabic "zarāfa". Apparently, it came to Arabic from African languages. Around the end of the 16th century this designation appears in Italian - "giraffa", Spanish and Portuguese - "girafa", and in French "girafe". And also, around this period, apparently, it was borrowed from French by the English language.

An interesting fact is that before this word was borrowed by English, this animal was called Camelopard. (Abbreviation from the Greek Camelopardalis). The combination of Camelos "Camel", because of the long neck and pardos "Leopard" (panther), because of spots on the body (Onions, 2003).

2) Apricot "There were fruit trees with two types of every fruit, pomegranates sweet and sour on the branches, almond-apricots, camphor-apricots and Khurasanian almonds, plims intertwined in the branches of ban trees, oranges gleaming like fiery torches, citrons weighing down the branches, lemons, the remedy for loss of appetite, sorel, which cures jaundice, and dates, red and yellow, on their parent trees, the creation of the Lord on high." (Lyons, 2008: night 630)

This example illustrates a number of fruit names. Three of them have Arabic roots.

Typically, words of Latin origin travel from Latin to French, and then end up in English. However, the "apricot" made a short southward detour. Initially, among the Greeks, this fruit sounded like "berikokkia." Then the Arabs borrowed this word, adding the article 
and it turned into "al-burquq." Thanks to the Arabic presence in Spain (711-1492 a.d.), the borrowing came into Spanish in the form of "albaricoque." Then in French - "abricot." This word first came to English in the form of 'abrecock,' but over time (probably influenced by the French) the sound "ck" changed to "t" and the word (1300 a.d.) acquired a modern look, used to this day (Online etymology dictionary, 2020).

Figure 1

\section{The way of borrowing of the word "giraffe" by English}

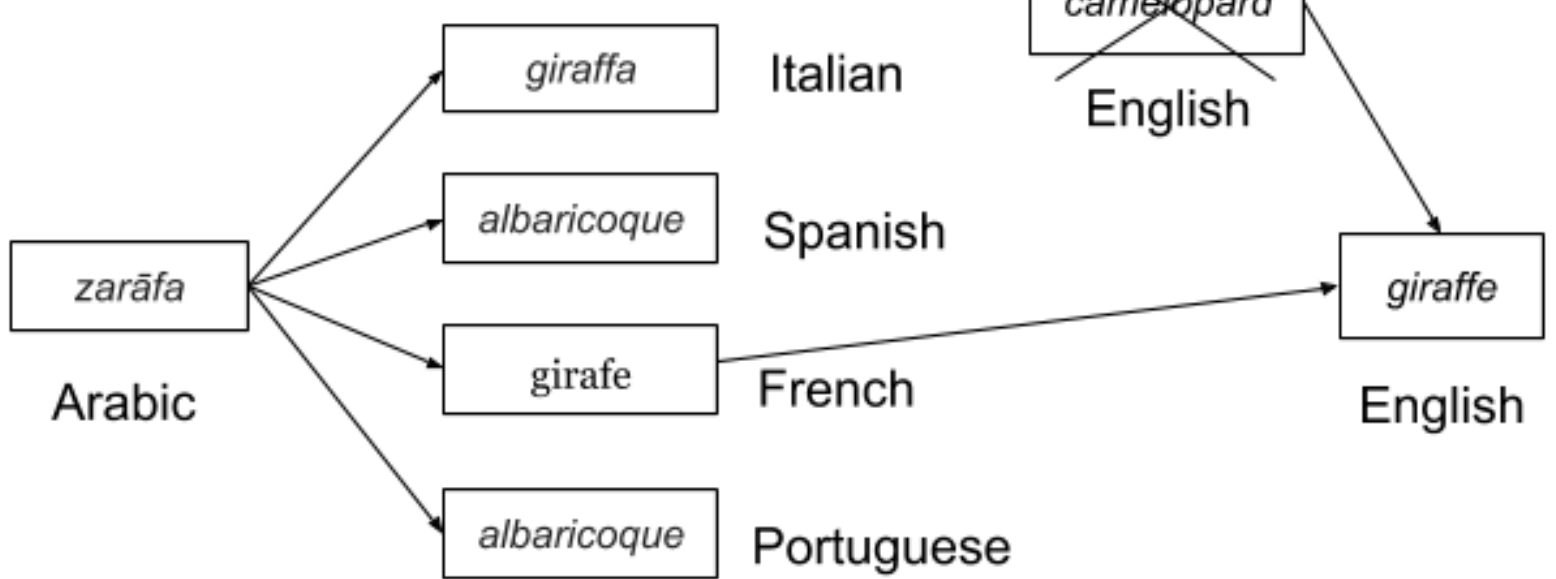

The way of borrowing of the word "apricot" by English

Figure 2

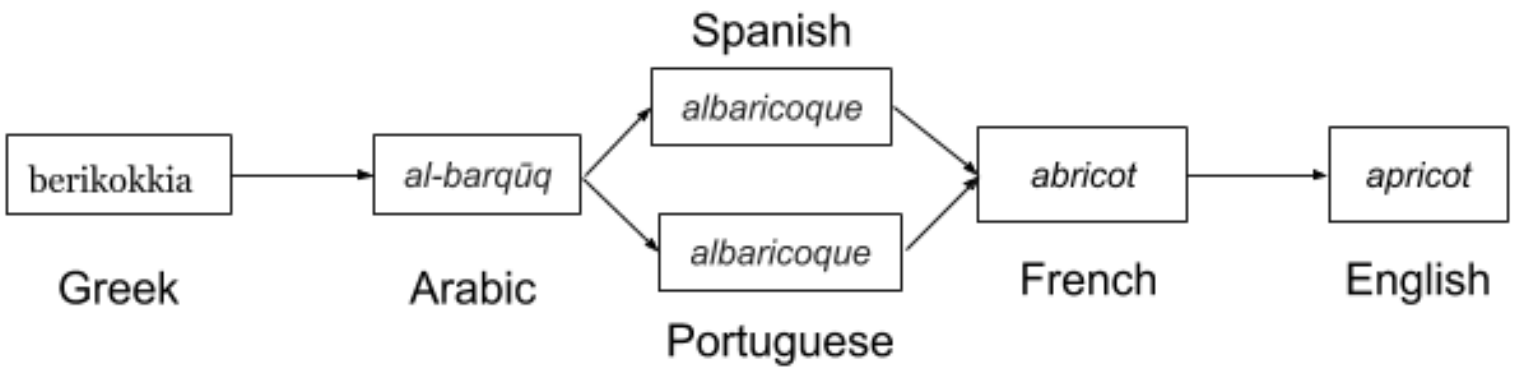

\section{3) Orange}

It is established that the roots of the name of this fruit date back to Sanskrit "naranga-s" (orange-tree). Then the Persians borrowed it in the form of "Narang." In this form, it fell into the Arabic language "nāranj." Only from the old French -
"Orenge," in English it acquired a modern form of "Orange." It has been used as an adjective for color since about the 1540s. Prior to this, words like citrine or saffron were used to describe the orange color. The first use of the phrase Orange juice dates back to 1723 (Online etymology dictionary, 2020).

Figure 3

The way of borrowing of the word "orange" by English

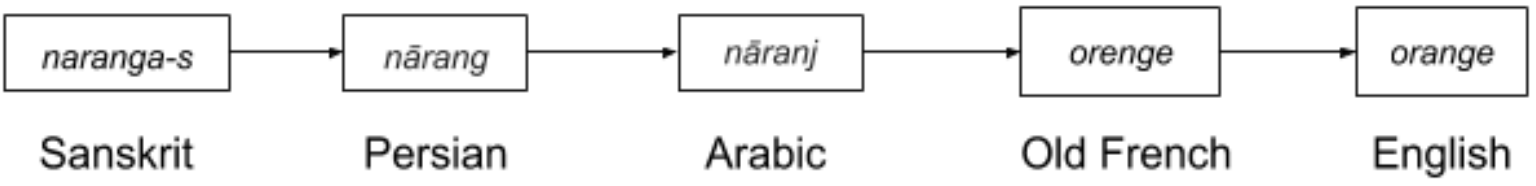




\section{4) Lemon}

In Arabic, the word "līmūn" means a common name for all fruits of this type. Around the 14th century, this word was borrowed by the Old French - "limon." In modern French, this token is also present, but has changed its meaning and today limes are called by this term (Online etymology dictionary, 2020).

The way of borrowing of the word "lemon" by English

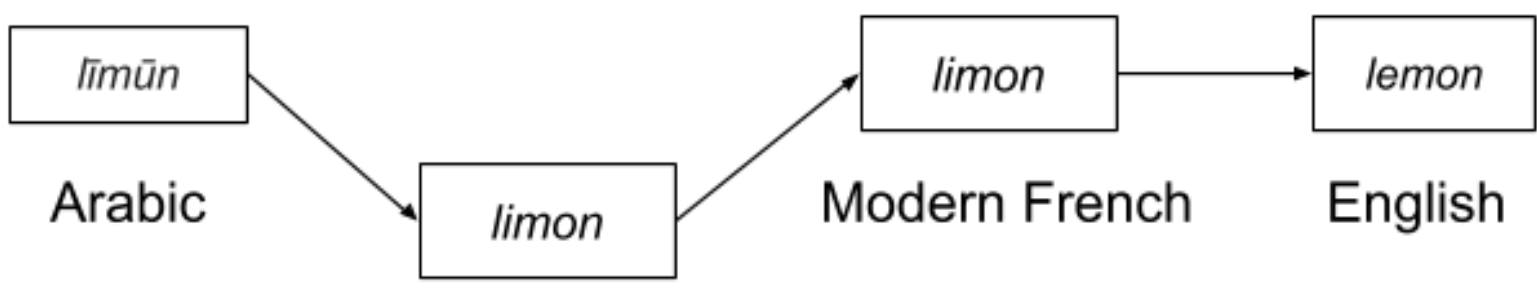

\section{Old French}

\section{5) Chemistry}

"He won renown for the depth of his knowledge of medicine, astronomy, geometry, astrology, chemistry, natural magic, and the spiritual sciences, as well as others." (Lyons, 2008: night 535)

Oddly enough, regarding the etymology of the word chemistry, there is still no clear answer. Scientists only agree that this word comes from "alchemy," which in turn was

Figure 4

borrowed from the Arabic "al-kīmiyā," where "al" is the Arabic definite article, and the root of the word comes from the ancient Greek "khemeioa." The first mention dates back to about the 300th year a.d. There is an assumption that the roots of the word go back to the ancient name of Egypt - Khemia, which literally means - black earth (Hoad, 1996).

The way of borrowing of the word "chemistry" by English

Figure 5

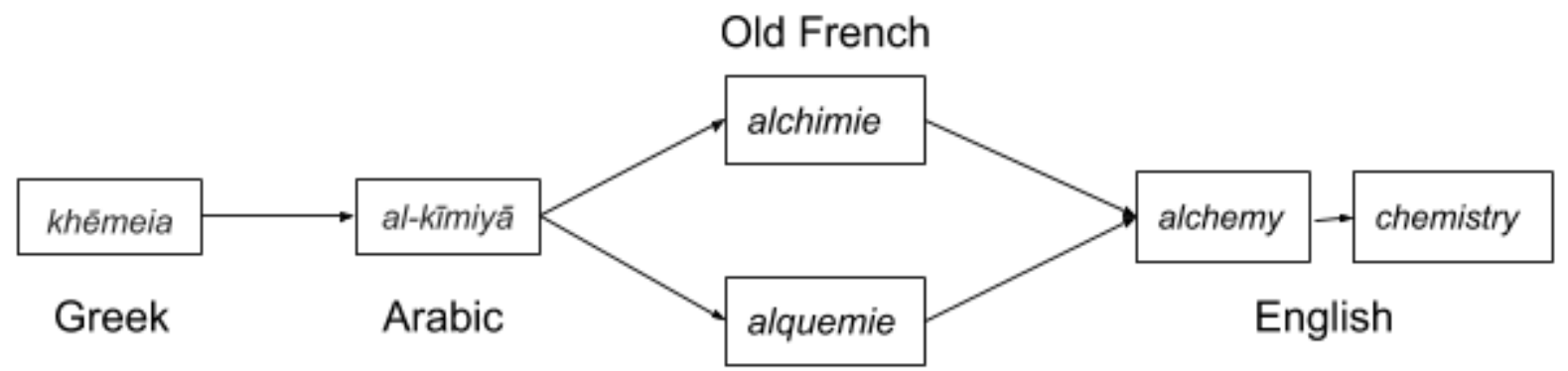

Medieval Latin

\section{6) Almanac}

"One day he summoned men of learning, astrologers, scientists, and almanac experts and told them to examine his horoscope to see whether God would grant him this wish." (Lyons, 2008: night 499)
The meaning of the word Almanac is interpreted as a collection of astronomical data. Presumably, the roots of this word date back to the Spanish-Arabian times of the conquest of the Iberian Peninsula by the Arabs (14th century), and meant "calendar." (Smith, 2007) 
The way of borrowing of the word "almanac" by English

Figure 6

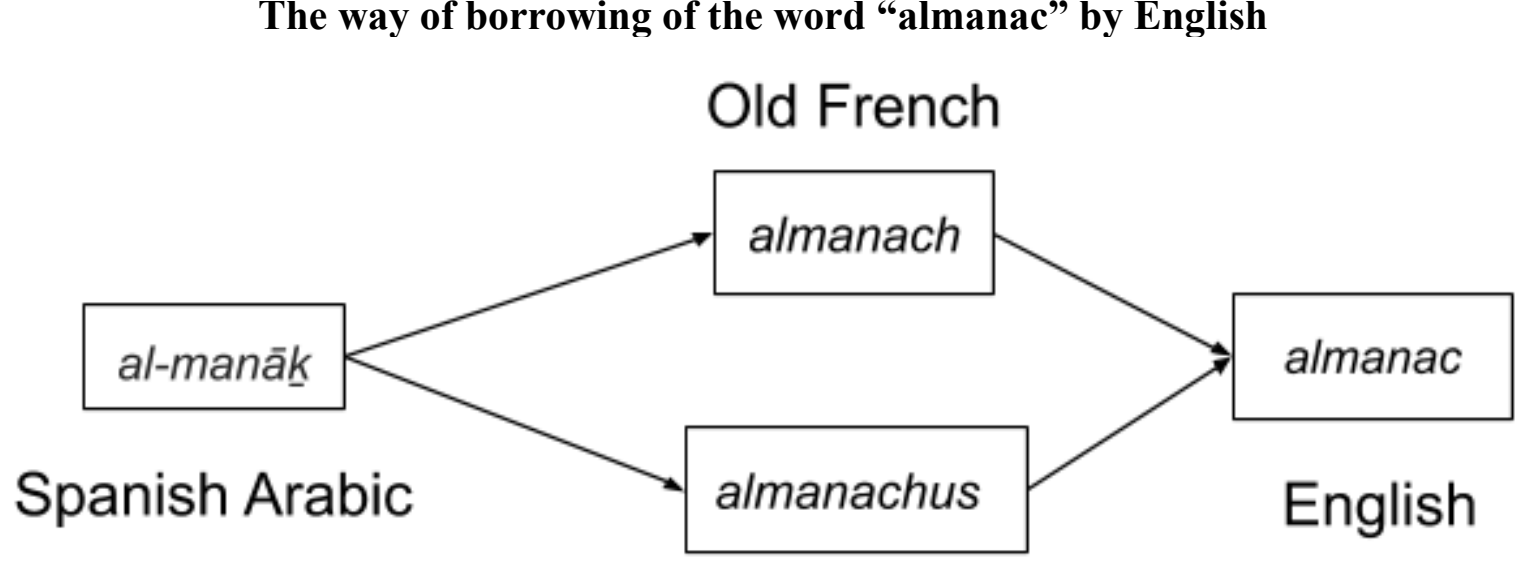

\section{Medieval Latin}

\section{7) Camphor}

"Whoever wants to get some camphor must use a long tool to bore a hole at the top of the tree and then collect what comes out." (Lyons, 2008: night 545)

According to the Oxford Dictionary, camphor is a white substance with a strong odor used in medicine as well as in the manufacture of plastic and in order to drive insects away from fabric clothing. This substance is obtained from trees in East Asia and Indonesia (Fassler, 2013). The etymology of this word has come a long way from Sanskrit - "karpūra," where it literally meant "the camphor tree", then, through the Malaysian, it was borrowed from Arabic, slightly changing its phonetic characteristics "kāfür." And subsequently, around the 14th century, it came to English through French and Latin (Merriam-Webster: 2019).

\section{The way of borrowing of the word "camphor" by English}

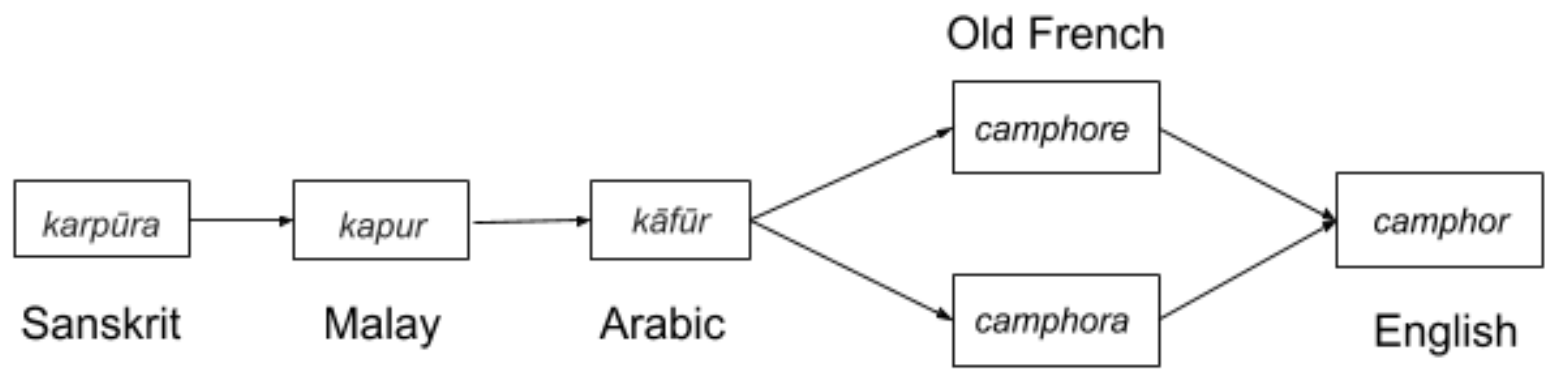

Medieval Latin

\section{8) Assassin}

"On the fourth day he appeared before the Khalfah, who asked him for the murderer. 'Can I see the invisible or search out the hidden?' answered Jafar. 'Can I find an unknown assassin in a whole cityful of people?" (Lyons, 2008: night 119)

The origin of this word comes from the territory of modern Lebanon during the
Crusades. According to the most common theory, a sect of Muslim fanatics led by Hassan-i Sabbah has settled in these mountains. This group of people was famous for the fact that they killed the leaders of the hostile clans under the influence of hashish (a cannabis-based narcotic substance). In Eastern Europe, they were assigned such a 
reputation around the 12-13th centuries (Dahler, 2013).

The word itself comes from the Arabic "hashīshīn" (the one who uses hash). The term was spread in Italy at the beginning of

\section{The way of borrowing of the word "assassin" by English}

the 14th and 15th centuries - "Assissini". In the middle of the 16th century, the word entered the French language, later it was borrowed by English.

\section{French}

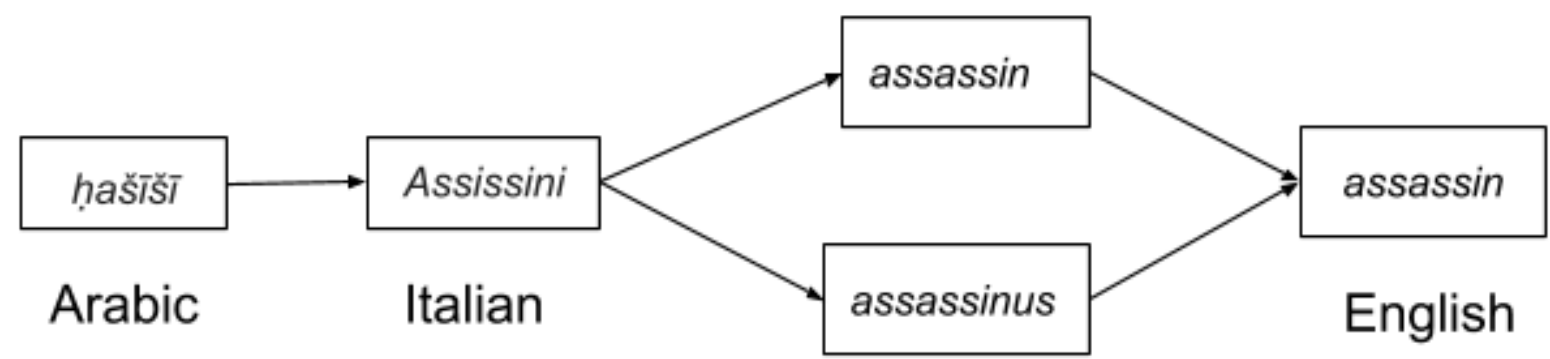

\section{Medieval Latin}

\section{9) Sheikh}

"And the sheikh, master of the gazelle, being greatly astonished, said: 'By Allah, your faith, my brother, is indeed a rare faith!" (Lyons, 2008: night 487)

The literal meaning of the Arabic "sheikh" (šayk) is translated as "old man". While the word itself comes from the verb "šākna", which means "to get older, grow old". In the records dated to the $1570 \mathrm{~s}$ it is found in the meanings: "head of the Arab family", as well as "head of the Muslim religion". The word gained universal fame in the Englishspeaking society after the publication of the novel in the Arabic setting of the British writer Edith Maud Hall "The Sheikh" in 1919. A movie version of the book under the same title soon followed (Cannon, 1994). The main role was played by Rudolf Valentino, thanks to whom in the 1920s everyone associated this word with a "strong and romantic Arabian lover". Nowadays, the meaning of the word is closer to its original and usually refers to the "ruler of the tribe", "member of the royal family." Usually, this title is awarded to a newborn man in the royal family.

\section{The way of borrowing of the word "sheikh" by English}

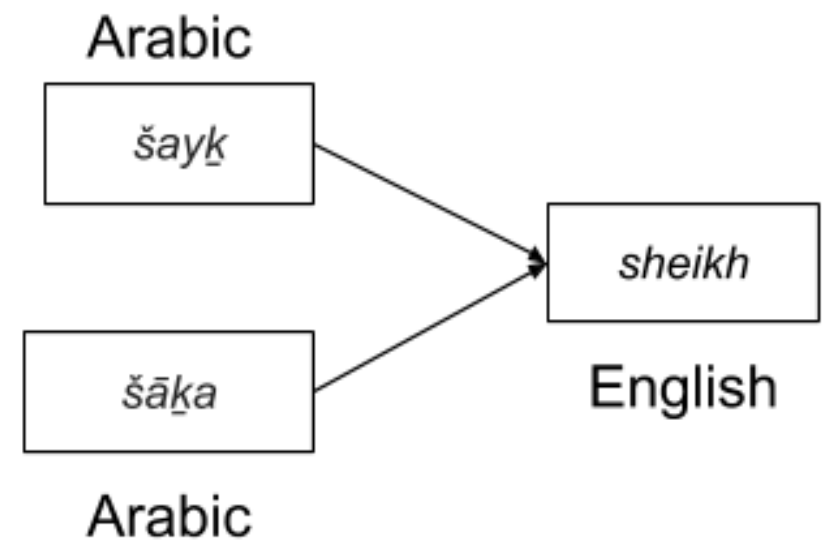


10) Gazelle - any of the many species of antelopes. The main habitat of these animals is the deserts, meadows, and savannahs of Africa. They can also be found in central Asia and in the south of the Indian peninsula.

The borrowing of this word in English dates from about 1600. Presumably, it was based on the northern Arabic pronunciation - "Ghazal" and passed into Spanish like "gacela" and Old French "gazel" in the 14th century (Merriam-Webster, 2019). After a while, the word began to be used in English.

The way of borrowing of the word "gazelle" by English

Figure 10

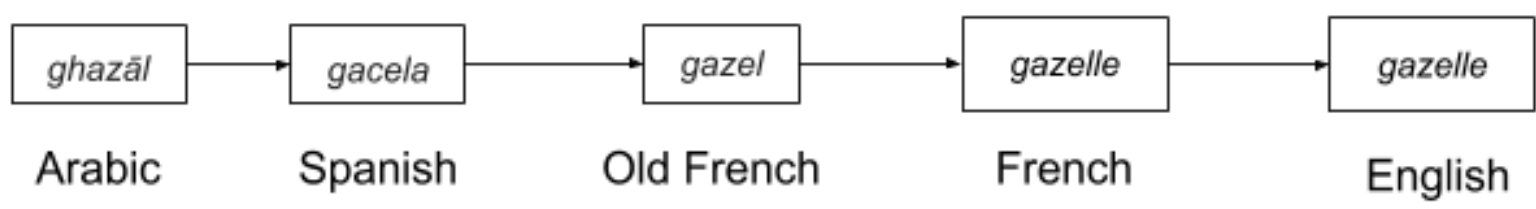

11) Allah

In the Muslim religion, the word Allah (Allāh) refers to the meaning of the one God. Etymologically, the term is supposedly a modified construction of "al-Ilāh" - "God" (lit.). The origin of the word may refer to the earliest Semitic writings, in which the words in the meaning of God looked like: "il", "el" and "eloah". The last two are even found in the Hebrew Bible. The word "Allah" has a strong association with the Islamic religion because of the special status of the Arabic language in the Quran - the holy scripture of Islam. It is believed that the original language in which the text of the Quran was written by the hand of God is Arabic. Thus, for Muslims, the Arabic language is of particular importance (Cannon, 1994).

Figure 11

The way of borrowing of the word "Allah" by English

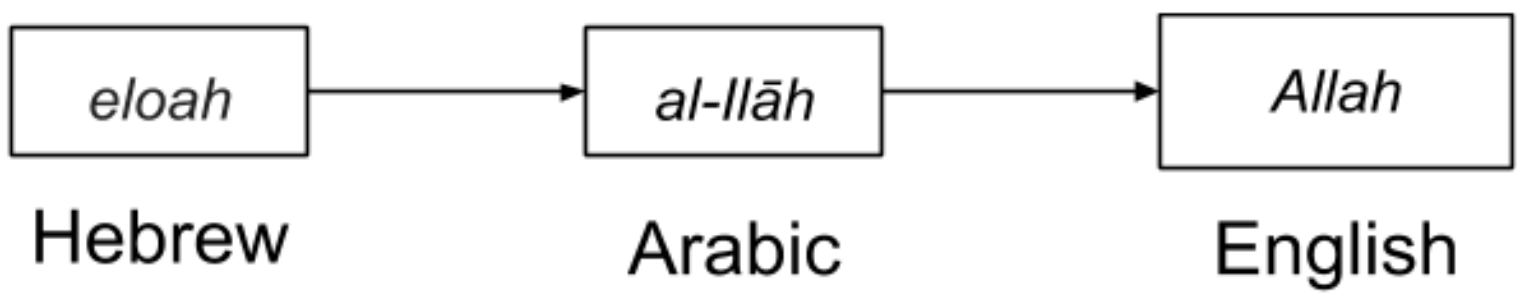

12) Sugar.

"...I have a guiltless love, dear lad, Which I should hide although you had

Thrown all the sweetness in eclipse

Of a thousand China trading ships

With the lithe verses of your hips

And the sugar of your lips."

(Lyon, 2008: night 112)

It is generally accepted that the word comes from the Arabic "sukkar". However, it is assumed that its ancestors originated from Persian and Sanskrit. Around the 12th century, the word is borrowed from the medieval Latin "succarum" and the old French "sucre". Soon after it came into use of the Old English language (13th century), the word had the form "sugre", but subsequently it took on that modern form in which we now know it (Darwish Hosam, 2015: 108).

Sugar was exotic for medieval Europe until the moment the Arabs began to cultivate it in Sicily and Spain. Subsequently, many European languages adopted it with minimal phonetic changes. 
The way of borrowing of the word "sugar" by English

Figure 12

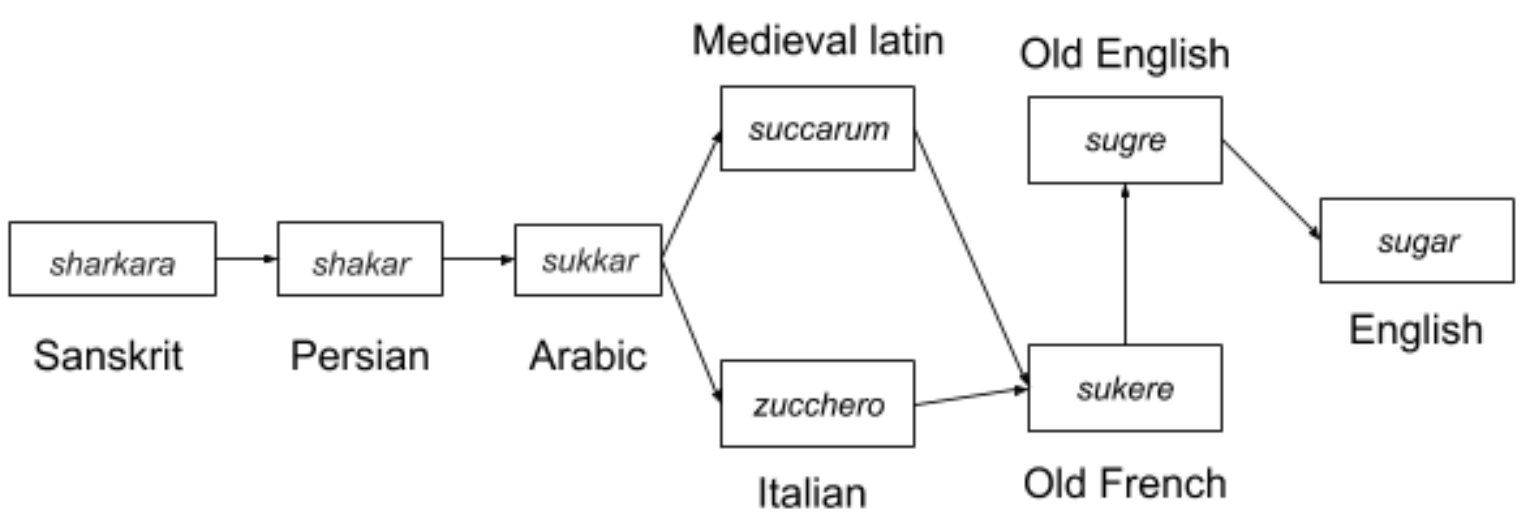

13) Mattress

"After a long conversation, he brought out a mattress and a quilt for me, and let me sleep that night in a corner of his shop." (Lyons, 2008: night 785)

The word "mattress" comes from the Arabic verb "taraha", which means "he threw (down)" with the addition of the noun prefix "ma-". Then, in combination with the Arabic definite article, presumably at the beginning of the 12th century in the territory of Sicily, this word was borrowed by the Catalan (almatrac), Spanish (almadraque) and the medieval Latin (matracium), which literally means "a thing thrown under your feet". Subsequently, the term appears in Italian (materasso) and in the ancient French (materas).

The first mention of this word in English dates from around the beginning of the 14th century, where the word was borrowed directly from French and had the same spelling. Obviously, over the time, it acquired a modern look and meaning - a component of the bed, in the form of a bag filled with soft and resilient material (Onions, 2003).

\section{The way of borrowing of the word "mattress" by English}

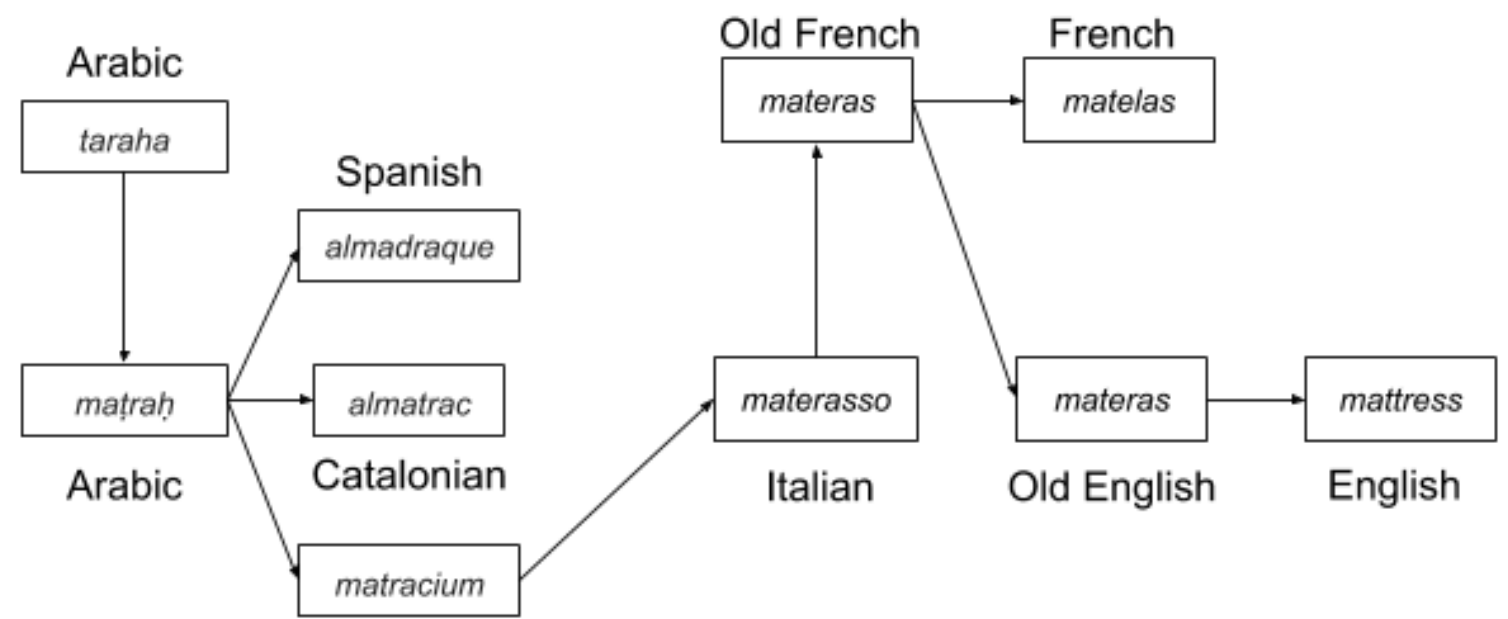

Medieval Latin 


\section{4) Massage}

"After a few moments of consideration, the old man covered the faces of the sleepers and, sitting on the ground before them, began to massage the feet of Ali-Nur, for whom he had taken a sudden liking." (Lyons, 2008: night 445)

Regarding the origin of the word "massage", there are two main theories. According to both of them, the word came into English from French, however, according to the first theory, the word came into French from colonial India, where the Portuguese used the word "amassar" (knead), which in its turn came into Portuguese from the Latin "massa" (mass, dough).

The second version involves borrowing the word by French from the Arabic "masser" (to massage), which comes from the verb "massa" (touch, feel) (Smith, 2007). Thus, the French could borrow this word during the Napoleonic military campaign in Egypt. This word begins to spread since 1819, in the meaning of "knead". It gained its modern interpretation a little later, in 1874.

Figure 14

\section{The way of borrowing of the word "massage" by English}

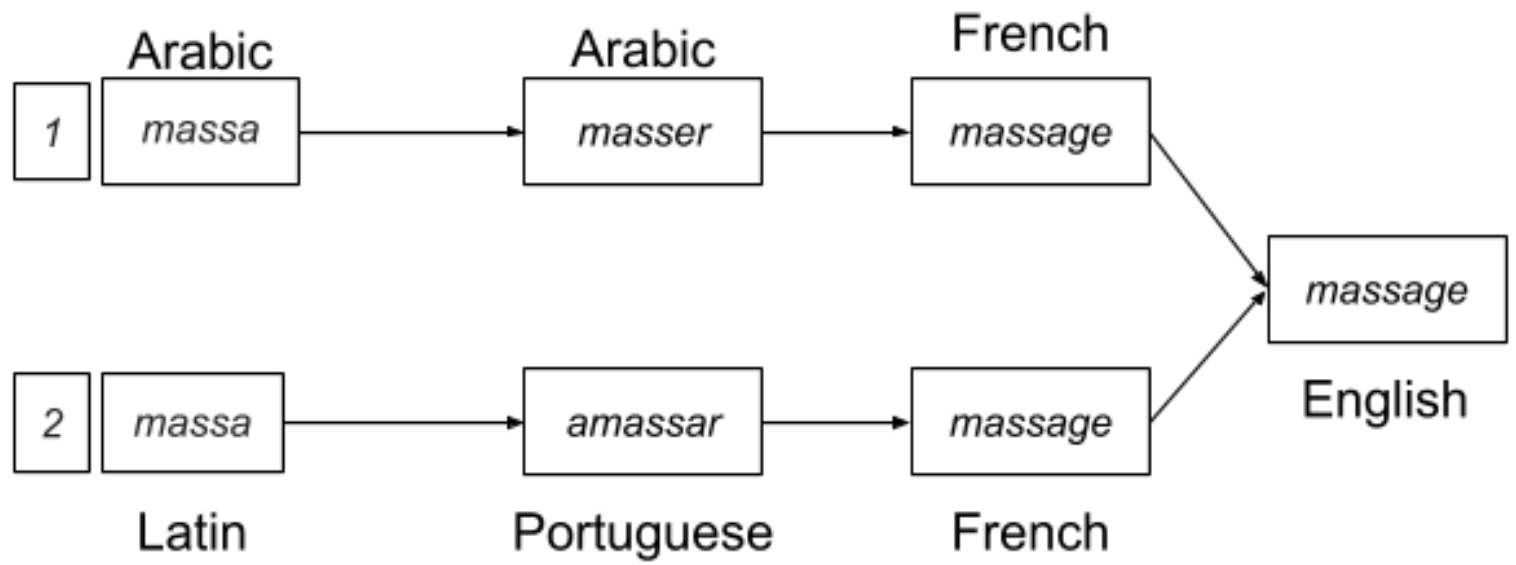

\section{5) Sherbet}

"Then she dressed him in clean clothes belonging to her husband, made him drink a glass of delicious sherbert, and sprinkled his face with rosewater." (Lyons, 2008: night 501)

Despite the fact that the word "sherbet" has been present in the English language for several centuries, its meaning has changed over time and differs from the modern interpretation. This word got into English directly from the Turkish language of the Ottoman Empire (̌serbet) and Persia (šarbat), meaning a traditional Middle Eastern sweet drink diluted with fruit syrup or juice. The word came into Turkish from Persia, and the Persian people had borrowed from Arabic (šarba), which literally means "drink", which in turn is formed from the verb "to drink" (šariba). By the way, the solid " $t$ " at the end of the word appeared due to the peculiarities of Turkish and Persian Arabic pronunciation (Abu Ghosha, 1977: 112).

The drink spread very quickly in eastern Europe at the beginning of the 16th century. Although, in English, the first mentions date back to the beginning of the 17th century, this drink was probably known even earlier. Throughout the 19th century, sherbert was used to mean a cool sweet drink with the addition of effervescent tasty powder, although nowadays, in Britain in particular, sherbert will most likely mean something like candy or powder that is eaten by dipping a finger into it. It is worth noting that even in the modern language there are several forms of the word. So, for example, sherbet (pronounced "sher-but") and sherbert (pronounced sher-bert) have the same meaning, although the "sherbert" variant is 
less used. The modern American interpretation distinguishes between the words "sherbet" and "sorbet". Sherbet is more like ice cream with milk and fruit, while sorbet has a simpler composition of ice and fruit juice (Bale, 2006).

\section{The way of borrowing of the word "sherbert" by English}

Figure 15

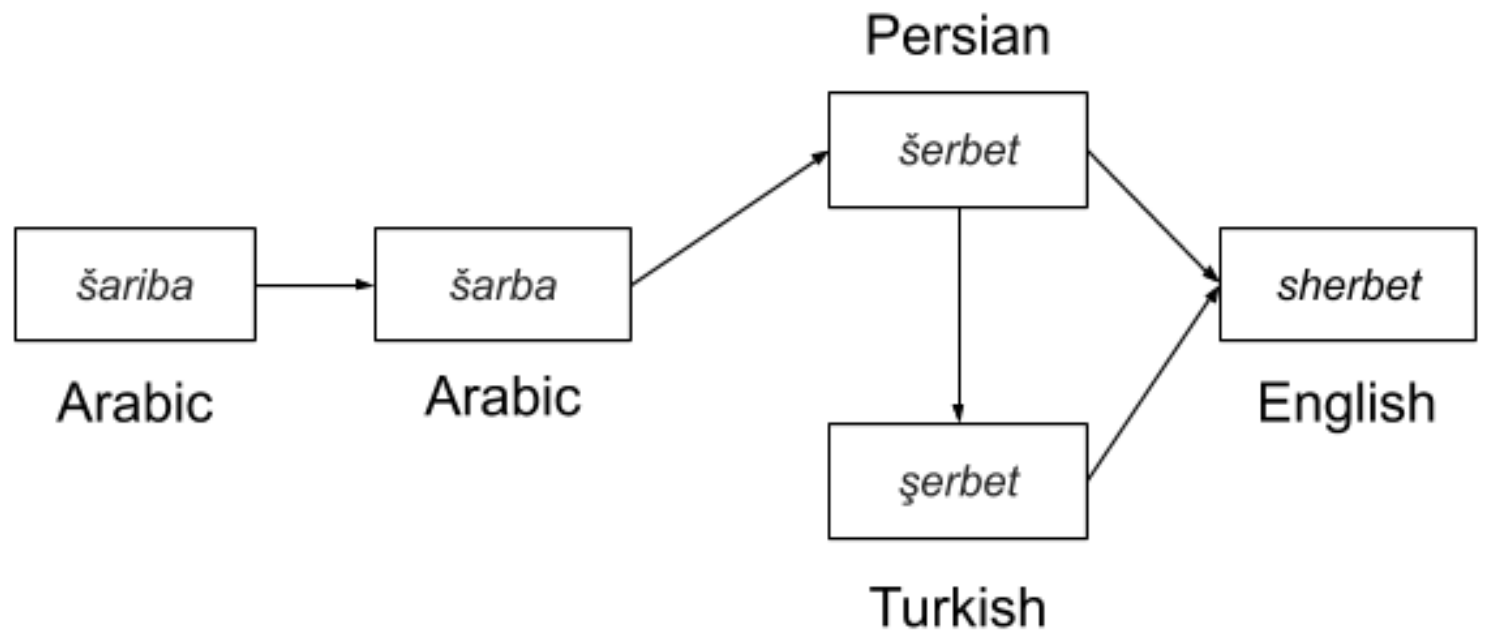

\section{Materials and methods}

The basis of this article were the work "One Thousand and One Nights" (translated into English by Anthony Galland), various etymological dictionaries, such as: MerriamWebster Online dictionary, The Oxford Dictionary of English Etymology, Online Etymology Dictionary, as well as articles and works of some famous researchers such as Jassem Z., Bale J., Adzieva E., Smith A.

\section{Results and conclusion}

We made a random sampling of English words with Arabic roots, in particular: giraffe, apricot, orange, lemon, chemistry, almanac, camphor, assassin, sheikh, gazelle, Allah, sugar, mattress, massage, sherbert. According to scientists, in the English language, there are about 170 borrowings from the Arabic language (Smith, 2007). About 50 of them came to English directly from Arabic, while the rest were derived through other languages. Based on the analysis, we were able to find out that only two words from the above list Sheikh and Allah, were borrowed directly from Arabic. Another one - sherbet, first came to Turkish, and only then to English. The rest, for the most part, became common in French and only after that they came into
English. This is explained, firstly, by the fact that the south of Europe, in particular Spain, was heavily influenced by Muslim culture for several centuries. Another reason why the French language has absorbed so many Arabic words is, of course, the Crusades, the initiative of which came largely from the French crusaders of the time. As a result, we can conclude that most of the Arabisms were borrowed by the English language not directly, but through other European languages and, in particular, French.

\section{References}

Abu Ghoush S., (1997). 10000 English Words from Arabic, Kuwait. Printing Agency.

Adzieva E. S., (2014). Usage of arabisms in fiction, Philological sciences. Issuies of theory and practice, Tambov: Gramota, № 10 (40): in three volumes, 16-20 (in Russian)

Anchi H., (2017). One Thousand and One Nights: Arabian Story-telling in world literature, Retrieved from: https://blogs.loc.gov/international-collections/ 2017/10/a-thousand-and-one-nightsarabian-story-telling-in-world-literature/

Bale J. (2006). Arabic and English: Four Hundred Ways of Describing a Camel, MED Magazine - Issue 39. 
Cannon G. H. and Kaye A. S., (1994). The Arabic Contributions to the English Language: An Historical Dictionary. Wiesbaden: Harrasso witz Verlag, Print

Daher J., (2013). Lexical Borrowing in Arabic and English. New York University

Darwish Hosam M., (2015). Arabic Loan Words in English Language, IOSR Journal Of Humanities And Social Science, 20, 7, 105-109

Fassler J., (2013). The Humanist message hidden amid the violence of One Thousand and one night, Retrieved from: https://www.theatlantic.com/ entertainment/archive/2013/06/the-humanistmessage-hidden-amid-the-violence-of-i-onethousand-and-one-nights-i/277210/ (last viewed December 2019)

Hoad T. F., (1996). The concise Oxford Dictionary of English Etymology, Oxford University Press

Hock H., (1986). Principles of historical linguistics. New York: Mouton de Gruyter.

Jassem Z., (2013). The Arabic Origins of "body part" terms in English and European languages: A lexical root theory approach. International Journal of Current Applied Linguistics and English Literature, 1, 2, 3-14.

Jassem, Z. A., (2013). The Arabic Origins of Common religious terms in English: A lexical root theory approach. International Journal of Applied Linguistics and English Literature, 1(6), 59-71.

Merriam-Webster Online dictionary, Retrieved from: https://www.merriamwebster.com/ from:

One Thousand and One Night, Retrieved https://en.wikipedia.org/wiki/One_Thousand_and _One_Nights
One Thousand and One Night: Favorites tales in three volumes (2009). Translation by Salye in 15 volumes : Eksmo.

Onions C.T., (2003). The Oxford Dictionary of English Etymology, Oxford University Press.

Online Etymology Dictionary, Retrieved from: http://www.etymonline.com (last viewed 01.01.2020)

Smith A., (2007). From Arabic to English. Saudi Aramco World Journal, 58, 2.

The Arabian Nights: Tales of 1,001 Nights, Volume 1 (2008). translated by Malcolm C. Lyons, Ursula Lyons, Robert Irwin (Penguin Classics).

The Arabian Nights: Tales of 1,001 Nights, Volume 2, (2008). translated by Malcolm C. Lyons, Ursula Lyons, Robert Irwin (Penguin Classics).

The Arabian Nights: Tales of 1,001 Nights, Volume 3, (2008), translated by Malcolm C. Lyons, Ursula Lyons, Robert Irwin (Penguin Classics).

The One thousand and One nights Persian origin, Retrieved from: http://exhibitions.slv.vic.gov.au/love-anddevotion/explore/stories-poems/1001-nights$\%$ E2\%80\%93-persian-origins

Wilson J., (2008). Arabic in Middle English, Retrieved from: http://homes.chass.utoronto.ca/ cpercy/courses/63 61Wilson.htm.

Конфликты интересов: у авторов нет конфликта интересов для декларации.

Conflicts of Interest: the authors have no conflict of interest to declare.

Alexander S. Eremin, Graduate Student, Belgorod State National Research University

Еремин Александр Сергеевич, аспирант Белгородского национального исследовательского университета 